To quote an outmoded cliché-“"The price of freedom is eternal vigilance." Unless consultants assume responsibilities and the added effort which this entails we shall see more and more examples as quoted by $\mathrm{Dr}$ Boulton and others. If medicine is to remain an independent profession we need to set an example to our juniors, who, fortunately, appear to be more aware of the problems which face them than do some of my consultant colleagues. The future of British medicine lies with the younger generation, who are, as $\mathrm{Mr}$ J McE Potter (21 August, p 479) says, more intelligent than ever before. They should be accorded the same courtesies as we extend to any colleague.

"The fault, dear Dr Boulton, is not in our stars, but in ourselves, that we have allowed ourselves to become underlings" (with apologies to the Bard). Royal United Hospital,
Bath

THEO SCHOFIELD

SIR,-I would like to draw attention to an increasing tendency of the new administrators in many areas to a worsening practice of asking for references at very short notice.

Today I received, on the precise day allocated for the interview, a request for a reference sent out by second class mail. The letter was delivered within the time allowed by the GPO, but even if it had been sent by first class mail it would have been unlikely to reach me in time to prepare a reference and make sure it arrived at area headquarters by the date it was requested. By the same post one of my staff, for whom the reference was required, received by second class mail and bearing the same postmark and date on the letter a request to attend for interview 100 miles away, a clearly almost impossible task.

This casual attitude to a most important matter is discourteous in the extreme and may well cost an applicant a job. In exceptional circumstances a telephone call would prevent such a situation. It also raises the question of the validity of any decision made by a committee under these circumstances.

D C BODENHAM

Department of Plastic and Jaw Surgery,

Frenchay Hospital,

Bristol

SIR,-Recent correspondents have rightly expressed criticism and concern over current administrative practices in the request and return of references for medical appointments (24 July, p 236, 14 August, p 424, 21 August, p 478, and 4 September, p 585).

We have lately been sent such a request (for the post of surgical registrar) which seemed to us to set altogether new and unwelcome standards. The document was the familiar cyclostyled letter, emanating from the office of the personnel officer of a neighbouring area health authority and returnable to him. The objectionable nine of its 16 lines of text must be quoted verbatim:

"In order to protect the public, the post for which application is being made is exempt from Section 4 (2) of the Rehabilitation of Offenders Act, 1974, by virtue of the Rehabilitation of Offenders Act, 1974 (Exceptions) Order, 1975. It is not, therefore, in any way contrary to the Act to reveal any information you may have concerning convictions which would otherwise be considered as 'spent,' in relation to this application and which you consider relevant to the applicant's suitability for employment. Any such information will be kept in strict confidence, and used only in consideration of the suitability of this applicant for a position where such an exemption is appropriate."

The innuendo is not only insulting but gratuitously so. The statutory duty to "protect" the public resides with the General Medical Council, which maintains a register of doctors adjudged fit to practise. It is a simple matter for an employing authority to verify the registration of its potential medical staff. The ethical obligation of individual medical referees is then simply to provide an honest testimonial as to an applicant's professional qualities.

We agree with your earlier correspondents that, wherever feasible, references should be submitted direct to the consultants concerned, who should be named in the advertisement; but failing that to a named senior medical administrator, not to anonymous lay intermediaries. Such a procedure would sometimes impose yet a further unpaid administrative burden upon clinicians, but the principle that medical matters should be dealt with by medical men is too important to be surrendered out of either indifference or inertia.

P J E WILSON J S WATERS

Morriston Hospital, Swansea

\section{Travellers' diarrhoea}

SIR,-There seem to be five different current medical attitudes to travellers' diarrhoea.

(1) Traditionalists hold that this is basically not an infectious disease and that chemoprophylaxis is therefore not indicated. This view has been restated in the British National Formulary 1976-78: "travellers' diarrhoea is frequently due to non-infective causes" (p 120) and "there is no evidence that antibiotics, sulphonamides or clioquinol are effective in the prophylaxis of travellers' diarrhoea" ( $p$ 39).

(2) Rationalists such as your contemporary ${ }^{1}$ accept that the recent study ${ }^{2}$ of participants in the gastroenterology congress at Mexico City confirms the earlier work that travellers' diarrhoea is usually due to enteropathic bacteria, especially Escherichia coli, ${ }^{3}$ but either deny or ignore the value of chemoprophylaxis

(3) Sceptics, as in your recent leading article (14 August, p 385), accept the evidence for enteropathic bacteria ${ }^{2} 3$ only reluctantly and then ask for all Koch's postulates, although doubting whether gastroenterologists would volunteer to eat their colleagues' faeca extracts. Fortunately no ethical committee need be asked to approve such a trial since it has occurred involuntarily after the Central Public Health Labroatory isolated $E$ coli O148K ?H28 from the faeces of $54^{\circ} \%$ of British troops developing diarrhoea within two weeks of arrival in Aden and never from healthy soldiers or those with shigella or salmonella diarrhoea. ${ }^{3}$ One of the assistants working on this project developed abdominal pain, profuse watery diarrhoea, malaise, and weakness but no fever. Faeces on the first and second days of his illness grew $E$ coli $\mathrm{O} 148 \mathrm{~K}$ ?H28, the diarrhoea stopped within 24 hours of treatment with oral colistin sulphate, and the faeces thereafter failed to grow this $E$ coli. ${ }^{3}$

(4) Defeatists such as you accept the evidence of controlled trials ${ }^{5}$ but then doubt either their practicality or their safety, joining the other group in merely recommending the traveller to rely on the old adages about care with food and water well summarised by the DHSS, ${ }^{6}$ although I doubt if most laymen would understand that the DHSS's coy sentence, "A high standard of personal hygiene is also of the greatest importance," means "the importance of washing the hands after visiting the WC." Certainly Streptotriad (streptomycin, sulphadimidine, sulphadiazine, and sulphathiazole) might "cause crystal deposition in the kidney." However, Sulphatriad was deliberately formulated with three separately soluble sulphonomides (sulphathiazole, sulphadiazine, and sulphamerazine), and May and Baker "have no records of any patient developing crystalluria while taking Streptotriad."

(5) Empiricists not only accept the evidence of controlled trials but actually prescribe chemoprophylactics with apparent success for their staff ${ }^{6-8}$ or their families. ${ }^{9}$

Clearly we need more controlled trials of chemoprophylaxis to convince groups 1-4. Perhaps the research committee of the British Society of Gastroenterology would arrange one for the next world congress? Not that we should be insular: the 24th Annual Meeting of the BSGE was smitten with travellers' diarrhoea in spite of the large quantities of alcohol British gastroenterologists reluctantly consume before during and after their annual dinners in order to produce the bactericidal gastric acid you demand.

J H BARON

St Charles's Hospital,
London W10

'Lancet, 1976, 2, 30 , 1976, 294, 1299.

Rowe, B, Taylor, J, and Bettelheim, K A, Lancet,

- Kean, B H, et al, Fournal of the American Medical Association, 1962, 180, 367.

s Turner, A C, British Medical fournal, 1967, 4, 653.

Turner, A C, Practitioner, 1971, 206, 615.

Sports Medicinet Bullin of the British Association of

Sports Medicine, 1968, 3, 13.

- Turner, A C, Lancet, 1976, 2, 320.

\section{Emergency medical care}

SIR,-Dr Hugh Conway (28 August, p 511) has demonstrated in Paisley that $50.9 \%$ of emergency medical ward admissions to his urban district general hospital were referred by general practitioners, while $37 \cdot 3 \%$ were self-referred. Currently in a neighbouring Glasgow teaching hospital, with a large GP health centre adjacent to it, we are studying similarly the mode of referral of such patients. Of the first 200 consecutive medical ward admissions studied, $172(86 \%)$ have been emergencies. Of these, $61.6 \%$ were referred by GPs, $11.6^{\circ} \%$ by the doctor deputising service, and $24.4 \%$ were self-referrals. The corresponding Paisley figures were $50.9 \%$, $6.8 \%$, and $37 \cdot 3^{\circ}$.

In view of Dr Conway's reference to public concern about the deputising service there may be some reassurance in our finding that in all 20 cases in our preliminary series thus referred there were telephone referral calls and accompanying admission letters compared with $93.4 \%$ of the GP referrals. In addition, the preadmission label was broadly in agreement with the discharge diagnosis in all 20 cases compared with $92 \cdot 2 \%$ of GP admissions. 